\title{
PENGARUH GAYA KEPEMIMPINAN TERHADAP MOTIVASI KERJA DAN KEPUASAN KERJA SERTA DAMPAK PADA KINERJA KARYAWAN (Studi Kasus BMT Bina Ihsanul Fikri Yogyakarta)
}

\author{
Andi Afrizal \\ Prodi Perbankan Syariah STIA Alma Ata Yogyakarta \\ Email: andiafrizal2008@yahoo.co.id
}

\begin{abstract}
The purpose of this study was to determine the effect of four kinds of leadership style path-goals are: directive leadership style, leadership style, supportive leadership style participatory and leadership style achievement orientation, on work motivation and job satisfaction and performance of employees at BMT Bina Ihsanul Fikri (BIF) in 2012. The data is taken from the total population of 62 people from sharing positions, the test data using multiple linear regression and path analysis in hypothesis testing. Results of the study, found that leadership style path goals positively affects employee performance mediated by motivation and job satisfaction of employees BMT BIF. The results could be used by future researchers.
\end{abstract}

Keywords: Path-goals, motivation, satisfaction, employee performance

\section{PENDAHULUAN}

Intermediasi keuangan selain dilakukan oleh bank-bank dapat juga dilakukan oleh lembaga keuangan non bank seperti halnya Baitul Maal wat Tamwil atau yang lebih dikenal dengan BMT atau Koperasi Jasa Keuangan Syariah (KJKS), yang merupakan lembaga keuangan mikro berazas syariah dan berbadan hukum koperasi, lembaga ini masih relatif baru dibandingkan dengan organisasi-organisasi intermediasi jasa keuangan lainya di Indonesia. Perubahan lingkungan Bisnis ini juga dialami oleh BMT Bina Ihsanul Fikri (BIF) merupakan salah satu BMT yang beroperasi di Daerah Istimewa Yogyakarta sejak tahun 1996, sebagai koperasi jasa keuangan syariah atau lembaga keuangan mikro menghadapi perubahan lingkungan bisnis dituntut untuk melakukan penyesuaian atau perubahan-perubahan secara internal berdasarkan situasi dan kondisi lingkungan bisnis saat ini.Kemampuan manajemen untuk mengelola organisasi dengan efektif dan efisien salah satu yang harus mendapatkan perhatian dari pihak manajemen atau pemimpin BMT BIF adalah pengelolaan sumber daya Insani atau karyawan. Karyawan

JESI JURNAL EKONOMI SYARIAH INDONESIA merupakan salah satu bentuk sumber daya insani dalam organisasi, untuk meningkatkan kompetensi BMT BIF, pihak manajemen atau pimpinan mencari gaya kepemimpinan yang cocok dapat meningkatkan kinerja karyawan dan juga antisipasi terhadap permasalahan-permasalahan pengelolaan sumber daya insani yang ada di BMT BIF kedepan, misalnya karyawan yang berkerja 
tidak sesuai dengan ketentuan perusahaan, karyawan yang tidak mematuhi aturan perusahaan, tingginya tingkat perpindahan karyawan, banyaknya keputusan-keputusan perusahaan yang berjalan lambat dan respon terhadap anggota atau calon anggota yang lambat, hubungan teman sekerja dan juga atasan. Kinerja karyawan tidak berdiri sendiri namun juga dipengaruhi oleh beberapa factor diantaranya; gaya kepemimpinan, motivasi kerja dan kepuasan kerja seperti yang disebutkan di atas.

\section{Gaya Kepemimpinan path-goals}

Kepemimpinan merupakan elemen yang penting dalam perusahaan. pola pikir yang mendasari teori teori path-goal adalah suatu model kontijensi kepemimpinan yang dikembangkan oleh Robert House, yaitu empat macam gaya kepemimpinan: direktif, soportif, partisipatif dan orietasi prestasi, perbedaan gaya kepemimpinan dan tipe imbalan akan mempengaruhi, motivasi, prestasi kerja, dan kepuasan kerja. Teori path-goal adalah suatu model kontijensi kepemimpinan yang dikembangkan oleh Robert House, yang menyaring elemen-elemen dari penelitian Ohio State tentang kepemimpinan pada inisiating structure dan consideration serta teori pengharapan motivasi pengikut. Dalam Robert E.Coffey,Curtis W.Cook dan Phillip L Hunsaker:

"The path goal leadership theory describes what the leader should do to motivate followers: clarify performance goals, show the acceptable paths or means for attaining them, make the path easier to travel, and provide reinforcing consequences for those who achieve satisfactory performance," (Coffey dan Hunsaker, $1994: 304$ ).

Pola pikir yang mendasari teori tersebut adalah bahwa perbedaan tipe imbalan dan perbedaan gaya kepemimpinan akan mempengaruhi, motivasi, prestasi, dan kepuasan bawahan juga seperti yang di sampaikan oleh Schariesheim dan Naider :

"Path-goal of leaderdhip is asituasional the theory based on assummption that effective leader behaviour has a positive imfact on subordinate job satisfaction,, it provides a functional approach to leadership, calling for a diagnosis of function which need to be fulfilled in subbordinates work environments for them to be motivated, perform at high levels, and be satisfied." (Schariesheim dan Naider: 1996).

Gaya kepemimpinan ini secara operasional diukur dengan menggunakan 4 (empat) macam gaya yang diadopsi dari teori kepemimpinan situasional yaitu kepemimpinan jalur tujuan (Path-Goal Model) Robert House.

\section{Kepemimpinan pengarah atau directive leadership (X1)}

Variabel gaya kepemimpinan direktif ini secara operasional diukur dengan menggunakan 5 (lima) indikator yaitu: Pemimpin memberitahukan kepada bawahan apa yang diharapkan dari mereka; Pemimpin tidak menunjukan rasa simpati terhadap permasalah karyawan; Pemimpin memberitahukan jadwal kerja yang harus disesuaikan dan standar kerja; Pemimpin memberi arahan secara spesifik tentang cara menyelesaikan tugas; dan Pemimpin menentukan dan perencanaan, koordinasi dan pengawasan kerja karyawan.

Andi

Afrizal

152

JURNAL EKONOMI SYARIAH INDONESIA, Volume V, No.2 Desember 2015 
Kepemimpinan pendukung atau supportive leadership (X2)

Variabel gaya kepemimpinan ini secara operasional diukur dengan menggunakan 5 (lima) indikator yaitu: Pemimpin bersifat ramah, Menunjukkan kepedulian akan kebutuhan bawahan, Pemimpin mengembangkan hubungan interpersonal yang menyenangkan diantar anggota kelompok, Pemimpinan memberikan dorongan pada saat karyawan sedang mengalami frustasi dan kecewa dan Pemimpin membantu pengembangan karir.

\section{Kepemimpinan partisipatif atau participative leadership (X3)}

Variabel gaya kepemimpinan ini secara operasional diukur dengan menggunakan 5 (lima) indikator yaitu: Pemimpin berkonsultasi dan mengumpulkan ide-ide dari karyawan, Pemimpin menggunakan saran dan ide karyawan sebelum mengambil keputusan, Pemimpinan bersama-sama karyawan dalam membuat keputusan, Pemimipin mendelegasikan tugas kepada karyawan, Pemimpin mampu mengatasi komplik.

\section{Kepemimpinan orientasi prestasi/achievement-oriented leadership(X4)}

Variabel gaya kepemimpinan partisipatif ini secara operasional diukur dengan menggunakan 5 (lima) indikator yaitu: Pemimpin menetapkan tujuan yang menantang dalam mencapai prestasi, pemimpin memberikan penghargaan terhadap pencapaian prestasi, pemimpin memberikan sanksi atau peringatan terhadap prestasi kerja yang rendah, pemimpin memperomosikan karyawan memiliki kinerja memuaskan, dan pemimpin mencari perbaikan meningkatkan kinerja karyawan.

\section{Motivasi kerja}

Motivasi memiliki keterkaitan atau pengaruh terhadap terhadap kinerja (Performance), seperti yang dinyatakan oleh Bohlander dan Snell (2004), kinerja dapat di pengaruhi oleh kemampuan kayawan, motivasi karyawan dan lingkungan. Motivasi faktor yang terkait dengan pekerjaan itu sendiri atau hasil langsung dari padanya seperti sifat pekerjaan, prestasi dalam pekerjaan, peluang promosi dan kesempatan untuk pengembangan diri dan pengakuan kinerja. Karena itu faktor motivasi ini berkaitan dengan tingkat kepuasan kerja (Hygine factors). Variabel motivasi kerja ini secara operasional diukur dengan menggunakan 4 (empat) indikator yaitu: Kebutuhan berprestasi: pekerjan memberikan prestasi, pekerjaan yang memiliki nilai; Pengakuan: memberikan pujian atas hasil kerja, penghargaan atas hasil kerja; Kesempatan karyawan untuk berkembang: jenjang karir yang jelas, kesempatan rotasi dan promosi, kesempatan pelatihan dan training; dan Tanggung jawab: pekerjaan yang memberikan tanggung jawab yang luas dan penuh dari perusahaan atau atasan dan wewenang pengambilan keputusan.

\section{Kepuasan Kerja karyawan (Z2)}

Kepuasan Kerja merupakan sikap (positif) tenaga kerja terhadap pekerjaannya, yang timbul berdasarkan penilaian mereka terhadap situasi kerja

Pengaruh Gaya mereka. Kepuasan kerja menyebabkan peningkatan kinerja sehingga pekerja yang puas akan lebih produktif, Gibson,(2000:110). Hubungan fungsional mencerminkan sejauh mana atasan membantu tenaga kerja untuk memuaskan nilai-nilai pekerjaan yang penting bagi tenaga kerja, seperti yang dinyatakan oleh 
Young jin (2006), House dan Mitchell (1974) "these Leader results because of their influential posture, ability to work effectively with others, and succes in generating worker satisfaction". Kepusan kerja memilik keterkaitan dengan gaya kepemimpinan ,atasan yang memiliki gaya pemimpin cocok bagi tenaga kerja, maka tenaga kerja akan meningkat motivasinya dan sekaligus dapat merasa puas dengan pekerjaannya, Kreitner dan Kinicki, (2001: 226) variabel kepuasan kerja karyawan ini secara operasional diukur dengan menggunakan 4 (empat) indikator yang diadopsi dari teori dua faktor Herzberg $F$ yaitu: yang merupakan indikator yang diadopsi dari teori motivator - higiene Frederick Herzberg yaitu : Kompensasi: gaji pokok, tunjangan kerja dan keluarga, insentif (bonus); Kondisi kerja: kantor yang strategis, peralatan dan perlengkapan kerja yang lengkap, fasilitas kantor yang lengkap; Sistem dan kebijakan perusahaan:keterbukaan perusahaan dalam kebijakan, kebijakan administrasi yang tidak kaku; Hubungan rekan kerja dan atasan: hubungan dengan rekan kerja terjalin baik, hubungan dengan atasan tenggang rasa dan positif.

\section{Kinerja Karyawan (Y)}

Penilaian kinerja karyawan sangat di perlukan bagi sebuah perusahaan atau organisasi secara umum. Terdapat dua kepentingan yaitu untuk karyawan itu bersangkutan dan kepentingan organisasi secara keseluruhan, bagi karyawan, dengan adanya penilaian memberikan umpan balik tentang usaha-usaha yang telah mereka lakukan dalam waktu yang telah ditetapkan yang pada akhirnya bermanfaat digunakan dalam rangka perbaikan atau peningkatan prestasi kerja, penyesuaian konpensasi, pengembangan karir, penghargaan prestasi karyawan secara objective yang merupakan bagian pemeliaharaan motivasi karyawan serta pemenuhan terhadap kepuasan kerja. Variabel kinerja karyawan ini secara operasional diukur dengan menggunakan dengan menggunakan 3 (indikator) yang diadopsi dari Meija yaitu: Kualitas kerja: pelaksanaan pekerjaan dengan cepat dan tepat, keterampilan yang dimiliki telah sesuai dengan pekerjaan,karyawan berhati-hati dalam pekerjaan; Kuantitas kerja: karyawan menyelesaikan pekerjaan sesuai target, karyawan tidak keberatan diberi tambahan tugas, karyawan tidak keberatan di beri tambahan tugas, karyawan tidak keberatan tugas lembur; dan Kemampuan dalam kerja sama: adanya kesetia kawan dan saling menbantu dalam bekerja, karyawan berkerja sama dengan atasan.

Ada pengaruh positif gaya kepemimpinan terhadap motivasi kerja pada karyawan BMT BIF baik secara parsial maupun simultan. Ada pengaruh positif gaya kepemimpinan terhadap kepuasan kerja pada karyawan pada BMT BIF baik secara parsial maupun simultan. Ada pengaruh positif gaya kepemimpinan terhadap kinerja karyawan pada BMT BIF baik secara parsial maupun simultan. Ada pengaruh positif motivasi kerja terhadap kinerja karyawan pada BMT BIF. Ada pengaruh positif kepuasan kerja terhadap kinerja karyawan BMT BIF. Ada pengaruh positif gaya kepemimpinan terhadap kinerja karyawan yang dimoderasi variabel motivasi kerja pada karyawan BMT BIF. Ada pengaruh positif gaya kepemimpinan terhadap kinerja karyawan BMT BIF yang di moderasi variabel kepuasan kerja. Ada pengaruh positif motivasi kerja terhadap kinerja karyawan BMT BIF yang dimoderasi variabel kepuasan kerja.

\section{Andi Afrizal}

JURNAL EKONOMI SYARIAH INDONESIA, Volume V, No.2 Desember 2015 


\section{METODOLOGI PENELITIAN}

Penelitian ini mengunakan penelitian Kuantatif. Tipe penelitian ini adalah deskriptif dan penelitian penjelasan (Explanatory research) adalah penelitian yang mencoba memberikan penjelasan hubungan antar variablevariabel penelitian dan menguji hipotesa yang telah di rumuskan sebelumnya, Singarimbun Effendi, (2001).Sedangkan metode penelitian adalah sensus, menurut Singgih Santoso (2008:80) sensus adalah penelitian yang dilakukan terhadap seluruh anggota populasi atau semua anggota populasi di jadikan sampel. Penggunaan sensus dikarenakan jumlah populasi sedikit dan mudah dalam pengumpulan data dan variabilitas setiap element relatif tinggi (hetrogen) dan bertujuan untuk menjelaskan karateristik setiap elemen dari populasi, Singarimbun, (1989:159). Anggota Populasi dalam penelitian ini terdiri dari seluruh pengelola atau karyawan yang terbagi beberapa bagian yaitu : Manager, kepala unit, marketing, casier, pembukuan, keamanan, staff pusat, dan office boy, bagian rumah tangga dan perlengkapan, semua bagian yang menjadi total populasi terdiri dari 66 karyawan BMT BIF yang lokasi kerja tersebar dalam sebelas tempat kerja, satu cabang utama, sepuluh cabang pembantu serta unit.

Agar mendapatkan data yang jelas dan lengkap dalam penelitian, untuk memperoleh data yang lengkap dan objektif penyusun mengunakan metode pengumpulan data sebagai berikut:

Suatu teknik pengumpulan data dengan cara serangkaian daftar pertanyaan yang secara logis atau pernyataan tertulis kepada responden untuk di jawab dan dinilai. Sumber data penelitian yang di peroleh secara langsung dari sumbernya yaitu karyawan BMT BIF Yogyakarta berupa tanggapan karyawan terhadap variabel-varabel yang berkaitan dengan gaya kepemimpinan, motivasi kerja, kepuasan kerja, terhadap kinerja karyawan. Kuisioner yang disusun mengunakan metode skala Likert dengan skala penilaian (skor) 1 sampai dengan 4 , dengan variasi jawaban untuk masingmasing item pertanyaan dengan jawaban $S S=$ sangat setuju, $S=$ setuju $T S=$ tidak setuju, dan STS=sangat tidak setuju. Masing-masing pilihan jawaban diberi nilai 1 untuk jawaban ekstrim negatif dan nilai 4 untuk jawaban ekstrim positif.

Dukumentasi adalah tehnik pengumpulan data data yang dilakukan dengan cara melakukan pencatatan-pencatatan atau pengambilan dokumendokumen dari tempat penelitian yang memiliki hubungan atau dapat dijadikan pendukung dalam penelitian ini.

Penelitian ini menggunakan alat analisa secara kuantitatif yaitu analisa jalur dengan regresi linier berganda. Dengan menggunakan persamaan regresi linear berganda akan dapat diketahui seberapa jauh variabel independen dapat mempengaruhi variabel variabel dependen. Beberapa alat uji regresi akan dilakukan diantaranya: Uji valid,Uji Reliabilitas dan uji asumsi klsik.

\section{PEMBAHASAN}

Penelitian ini akan menggunakan regresi,linear berganda dengan program SPSS, untuk membuktikan hipotesa yang telah disusun dengan

Pengaruh urutan sebagai berikut:

Gaya 
Pengaruh gaya kepemimpinan secara parsial dan simultan terhadap motivasi kerja

Tabel 1. Hasil Uji t

\begin{tabular}{|c|c|c|c|c|c|c|}
\hline & \multirow[t]{2}{*}{ Model } & \multicolumn{2}{|c|}{$\begin{array}{l}\text { Unstandardized } \\
\text { Coefficients }\end{array}$} & \multirow{2}{*}{$\begin{array}{l}\text { Standardized } \\
\text { Coefficients } \\
\text { Beta }\end{array}$} & \multirow[t]{2}{*}{$\mathrm{t}$} & \multirow[t]{2}{*}{ Sig. } \\
\hline & & B & Std. Error & & & \\
\hline \multirow{5}{*}{1} & (Constant) & 1.958 & 1.077 & & 1.831 & .072 \\
\hline & Direktif & -.191 & .288 & -.075 & -.664 & .510 \\
\hline & Suportif & -201 & .228 & 101 & -881 & .382 \\
\hline & Partisifatif & .409 & .144 & .339 & 2.849 & .006 \\
\hline & Prestasi & .366 & .131 & .344 & 2.801 & .007 \\
\hline
\end{tabular}

Dari table uji -t diatas tersebut Gaya kepemimpinan direktif memiliki nilai signifikan 0.510 dengan tingkat singnifikan 0.510 lebih besar $\geq 0.05$. Dari uji secara parsial, tidak terpenuhi,yaitu: gaya kepemimpinan direktif, secara parsial tidak pengaruh terhadap variabel dependen motivasi kerja. Gaya kepemimpinan suportif memiliki nilai signifikan 0.382 dengan tingkat singnifikan 0.382 lebih besar $\geq 0.05$ Dari uji secara parsial, tidak terpenuhi, yaitu :gaya kepemimpinan suportif, secara parsial tidak berpengaruh terhadap variabel dependen motivasi kerja. Gaya kepemimpinan partisipatif memiliki nilai signifikan 0.006 dengan tingkat singnifikan 0.006 lebih kecil $\leq 0.05$ dari uji- $\mathrm{t}$ dapat dinyatakan variabel gaya kepemimpinan partisifatif memililiki atau ada pengaruh terhadap motivasi kerja.Dari uji secara parsial, maka terpenuhi,yaitu : gaya kepemimpinan partisipatif, secara parsial memiliki pengaruh signifikan terhadap variabel dependen motivasi kerja. Gaya kepemimpinan orientasi prestasi memiliki nilai signifikan 0.007 , dengan nilai singnifikan 0.007 lebih kecil $\leq 0.05$, dari uji- t dapat dinyatakan variabel gaya kepemimpinan orientasi prestasi memililiki pengaruh terhadap motivasi kerja. Dari uji secara parsial, terpenuhi yaitu: gaya kepemimpinan orintasi prestasi, secara parsial memiliki pengaruh signifikan terhadap variabel dependen motivasi kerja.

Tabel 2. Hasil Uji F

\begin{tabular}{llrrrrr}
\hline Model & $\begin{array}{c}\text { Sum of } \\
\text { Squares }\end{array}$ & df & \multicolumn{1}{c}{$\begin{array}{c}\text { Mean } \\
\text { Square }\end{array}$} & F & Sig. \\
\hline \multirow{2}{*}{1} & Regression & .958 & 4 & .239 & 6.458 & $.000^{\mathrm{b}}$ \\
\cline { 2 - 8 } & Residual & 2.114 & 57 & .037 & & \\
\cline { 2 - 8 } & Total & 3.072 & 61 & & & \\
\hline
\end{tabular}

Pengaruh gaya kepemimpinan direktif, suportif, partisipatif, dan orientasi prestasi secara simultan terhadap motivasi kerja,hasil tabel bahwa dengan tingkat signifikansinya 0,00. Dengan alfa sebesar 0,05, secara simultan variabel independen : kepemimpinan direktif, suportif, partisipatif dan orientasi prestasi memiliki pengaruh yang positif secara bersama-sama terhadap variabel dependen yaitu motivasi kerja. maka terpenuhi,yaitu empat gaya kepemimpinan yaitu gaya direktif, gaya suportif, gaya partisipatif, dan gaya orientasi prestasi, secara bersama - sama memiliki pengaruh signifikan terhadap variabel dependen motivasi kerja. 
Tabel 3. Hasil Uji $\mathbf{R}^{2}$

\begin{tabular}{crrrr}
\hline Model & R & R Square & $\begin{array}{c}\text { Adjusted R } \\
\text { Square }\end{array}$ & $\begin{array}{c}\text { Std. Error of the } \\
\text { Estimate }\end{array}$ \\
\hline 1 & $.558^{\mathrm{a}}$ & .312 & .264 & .19257 \\
\hline
\end{tabular}

Predictors: (Constant), Prestasi, Suportif, Direktif, Partisif

Hasil nilai koefisien determinasi sebesar 312 seperti terlihat dalam tabel memberikan arti bahwa motivasi kerja dijelaskan oleh variable independen gaya kepemimpinan direktif, suportif, partisipatif, orientasi prestasi sebesar $31.2 \%$, sedangkan $68,8 \%$ dijelaskan oleh variabel yang lain.

\section{Pengaruh gaya kepemimpinan secara parsial dan simultan terhadap kepuasan kerja}

Tabel 4. Hasil Uji t

\begin{tabular}{|c|c|c|c|c|c|c|}
\hline & \multirow{2}{*}{ Model } & \multicolumn{2}{|c|}{$\begin{array}{c}\text { Unstandardized } \\
\text { Coefficients }\end{array}$} & \multirow{2}{*}{$\begin{array}{c}\begin{array}{c}\text { Standardized } \\
\text { Coefficients }\end{array} \\
\text { Beta }\end{array}$} & \multirow[b]{2}{*}{$\mathrm{t}$} & \multirow{2}{*}{ Sig. } \\
\hline & & $\mathrm{B}$ & $\begin{array}{l}\text { Std. } \\
\text { Error }\end{array}$ & & & \\
\hline \multirow{5}{*}{1} & (Constant) & 1.927 & .731 & & 2.635 & .011 \\
\hline & Direktif & .504 & 197 & .329 & 2.560 & .013 \\
\hline & Suportif & -.153 & .156 & -.128 & -.984 & .329 \\
\hline & Partisif & .043 & .098 & .060 & .442 & .660 \\
\hline & Prestasi & -.018 & .089 & -.028 & -.197 & .844 \\
\hline
\end{tabular}

Dependent Variable: Kepuasan

Dari table uji-t diatas tersebut.dapat disimpulkan bahwa :Gaya kepemimpinan direktif memiliki nilai signifikan 0.013 dengan tingkat singnifikan 0.01 lebih kecil $\leq 0.05$. Dari uji- $\mathrm{t}$ dapat dinyatakan variabel gaya kepemimpinan direktif memililiki pengaruh terhadap kepuasan kerja, dari uji secara parsial, maka terpenuhi, yaitu: gaya kepemimpinan direktif, secara parsial berpengaruh terhadap variabel dependen kepuasan kerja. Gaya kepemimpinan suportif memiliki nilai signifikan 0.329 dan dengan tingkat singnifikan 0.329 lebih besar $\geq 0.05$, dari uji- $\mathrm{t}$ dapat dinyatakan variabel gaya kepemimpinan suportif tidak memiliki pengaruh terhadap kepuasan kerja. Dari uji secara parsial, maka tidak terpenuhi,yaitu gaya kepemimpinan suportif, secara parsial tidak berpengaruh terhadap variabel dependen kepuasan kerja.gaya kepemimpinan partisipatif memiliki nilai signifikan 0.660 dan dengan tingkat singnifikan 0.66 lebih besar $\geq 0.05$ dinyatakan variabel gaya kepemimpinan partisifatif tidak memililiki atau tidak ada pengaruh terhadap kepuasan kerja. Dari uji secara parsial, maka disimpulkan tidak terpenuhi, yaitu: gaya kepemimpinan partisifatif, secara parsial tidak berpengaruh terhadap variabel dependen kepuasan kerja. Gaya kepemimpinan orientasi prestasi memiliki nilai signifikan 0.844 dengan tingkat singnifikan 0.844 lebih besar $\geq 0.05$ variabel gaya kepemimpinan orientasi prestasi tidak memililiki pengaruh terhadap kepuasan kerja. Dari uji secara parsial, maka tidak terpenuhi, yaitu: gaya kepemimpinan orintasi

Pengaruh Gaya prestasi, secara parsial tidak berpengaruh terhadap variabel dependen kepuasan kerja. 
Tabel 5. Hasil Uji F

\begin{tabular}{rlrrrrr}
\hline \multirow{2}{*}{ Model } & $\begin{array}{r}\text { Sum of } \\
\text { Squares }\end{array}$ & df & & $\begin{array}{c}\text { Mean } \\
\text { Square }\end{array}$ & \multicolumn{1}{l}{ F } & \multicolumn{1}{c}{ Sig. } \\
\hline \multirow{3}{*}{1} & Regression & .120 & 4 & .030 & 1.736 & $.155^{\text {b }}$ \\
\cline { 2 - 8 } & Residual & .988 & 57 & .017 & & \\
\cline { 2 - 8 } & Total & 1.108 & 61 & & & \\
\hline
\end{tabular}

Dependent Variable: Kepuasan

F digunakan untuk melihat, apakah variabel secara simultan mempengaruhi variabel kepuasan kerja. Dengan tingkat signifikansinya 0,155, dengan tingkat singnifikan 0.15 lebih besar $\geq 0.05$ dengan demikan secara simultan variabel independen: kepemimpinan direktif, suportif, partisipatif dan orientasi prestasi tidak memiliki pengaruh yang positif secara bersamasama terhadap variabel dependen yaitu kepuasan kerja. Maka tidak terpenuhi, yaitu: gaya kepemimpinan direktif, gaya kepemimpinan suportif, gaya kepemimpinan partisipatif, dan gaya kepemimpinan orientasi prestasi, secara bersama-sama atau simultan tidak memiliki pengaruh yang signifikan terhadap variabel dependen kepuasan. kerja.

Tabel 6. Hasil Uji $\mathbf{R}^{2}$

\begin{tabular}{ccccc}
\hline Model & $\mathrm{R}$ & R Square & $\begin{array}{c}\text { Adjusted } \mathrm{R} \\
\text { Square }\end{array}$ & $\begin{array}{c}\text { Std. Error of the } \\
\text { Estimate }\end{array}$ \\
\hline 1 & $.330^{\mathrm{a}}$ & .109 & .046 & .13166 \\
\hline
\end{tabular}

Pengaruh gaya kepemimpinan secara parsial dan simultan terhadap kinerja

Tabel 7. Hasil Uji t

\begin{tabular}{|c|c|c|c|c|c|c|}
\hline & \multirow{2}{*}{ Model } & \multicolumn{2}{|c|}{$\begin{array}{c}\text { Unstandardized } \\
\text { Coefficients }\end{array}$} & \multirow{2}{*}{$\begin{array}{c}\begin{array}{c}\text { Standardized } \\
\text { Coefficients }\end{array} \\
\text { Beta }\end{array}$} & \multirow{2}{*}{$\mathrm{t}$} & \multirow{2}{*}{ Sig. } \\
\hline & & B & $\begin{array}{l}\text { Std. } \\
\text { Error }\end{array}$ & & & \\
\hline \multirow{5}{*}{1} & (Constant) & .893 & 1.233 & & .724 & .472 \\
\hline & Direktif & -.390 & .332 & -.101 & -1.174 & .245 \\
\hline & Suportif & .545 & .263 & -.044 & 2.073 & .043 \\
\hline & Partisif & .344 & .166 & .251 & 2.076 & .042 \\
\hline & Prestasi & .274 & .151 & .280 & 1.818 & .074 \\
\hline
\end{tabular}

Dependent Variable: Kinerja

Dari tabel uji-t di atas tersebut dengan alpha a $95 \%$ diperoleh nilai 0,05. Dapat disimpulkan bahwa :

Gaya kepemimpinan direktif memiliki nilai signifikan 0.245 , dengan tingkat singnifikan 0.245 lebih besar $\geq 0.05$, dari uji-t dinyatakan variabel gaya kepemimpinan direktif tidak ada pengaruh terhadap kinerja. Dari uji secara parsial, maka tidak terpenuhi,yaitu: gaya kepemimpinan direktif, secara parsial tidak berpengaruh terhadap variabel dependen kinerja. Gaya kepemimpinan suportif memiliki nilai signifikan 0.043 dan dengan tingkat singnifikan 0.04 lebih kecil $<0.05$ dari uji- t dapat dinyatakan variabel gaya kepemimpinan direktif memiliki pengaruh terhadap kinerja. Dari uji secara parsial, maka terpenuhi,yaitu; gaya kepemimpinan suportif, secara parsial berpengaruh terhadap variabel dependen motivasi kerja. Gaya kepemimpinan partisipatif memiliki nilai signifikan 0.042 dengan tingkat singnifikan 0.04

Andi

Afrizal

158

JURNAL EKONOMI SYARIAH INDONESIA, Volume V, No.2 Desember 2015 
lebih kecil $\leq 0.05$, dari uji-t dapat dinyatakan variabel gaya kepemimpinan partisipatif memililiki atau ada pengaruh terhadap kinerja. Dari tabel tersebut berarti bahwa variabel gaya kepemimpinan partisipatif berpengaruh signifikan terhadap kinerja. Dari uji secara parsial, maka disimpulkan terpenuhi, yaitu : gaya kepemimpinan partisifatif, secara parsial memiliki pengaruh signifikan terhadap variabel dependen kinerja.Gaya kepemimpinan orientasi prestasi memiliki nilai signifikan 0.074 , dengan tingkat singnifikan 0.07 lebih besar $\geq 0.05$, dari uji- $t$ dapat dinyatakan variabel gaya kepemimpinan orientasi prestasi tidak memililiki pengaruh terhadap kinerja. Dari uji secara parsial, maka tidak terpenuhi, yaitu: gaya kepemimpinan orintasi prestasi, secara parsial tidak memiliki pengaruh signifikan terhadap variabel dependen motivasi kerja.

Tabel 8. Hasil Uji - F

\begin{tabular}{|c|c|c|c|c|c|c|}
\hline & Model & $\begin{array}{l}\text { Sum of } \\
\text { Squares }\end{array}$ & Df & $\begin{array}{c}\text { Mean } \\
\text { Square }\end{array}$ & $\mathrm{F}$ & Sig. \\
\hline \multirow{3}{*}{1} & Regression & .986 & 4 & .247 & 5.004 & $.002^{\mathrm{b}}$ \\
\hline & Residual & 2.809 & 57 & .049 & & \\
\hline & Total & 3.795 & 61 & & & \\
\hline
\end{tabular}

Dependent Variable: Kinerja

Uji F digunakan untuk melihat, apakah variabel secara simultan mempengaruhi variabel motivasi kerja. diperoleh hasil, bahwa uji $\mathrm{F}$ dengan tingkat signifikan 0,002. Dengan signifikan sebesar 0,002 lebih kecil $<0.05$ maka Ho di tolak, dan Ha diterima dengan demikan secara simultan variabel independen: kepemimpinan direktif, suportif, partisipatif dan orientasi prestasi memiliki pengaruh positif secara bersama-sama terhadap variabel dependen yaitu kinerja. maka terpenuhi,yaitu; empat gaya kepemimpinan yaitu gaya kepemimpinan direktif, gaya kepemimpinan suportif, gaya kepemimpinan partisipatif, dan gaya kepemimpinan orientasi prestasi, secara bersama - sama memiliki pengaruh yang signifikan terhadap variabel dependen kinerja.

Tabel 9. Hasil Uji R ${ }^{2}$

\begin{tabular}{crrrr}
\hline Model & R & R Square & Adjusted R Square & $\begin{array}{c}\text { Std. Error of the } \\
\text { Estimate }\end{array}$ \\
\hline 1 & $.510^{\mathrm{a}}$ & .260 & .208 & .22197 \\
\hline
\end{tabular}

Analisa determinasi atau $\mathrm{R}^{2}$ digunakan untuk mengetahui seberapa baik garis regresi (variabel independen) menjelaskan perilaku variabel dependen. (Widarjono, 2010). Dengan menggunakan program SPSS, hasil lihat tabel, maka diperoleh hasil nilai koefisien determinasi sebesar 260 seperti terlihat dalam tabel memberikan arti bahwa kinerja dijelaskan oleh variabel independen kepemimpinan direktif, suportif, partisifatif, orientasi prestasi sebesar $26.0 \%$, sedangkan 74,0 \% dijelaskan oleh variabel yang lain.

\section{Pengaruh} Gaya

\section{Pengaruh motivasi kerja terhadap kinerja karyawan}

Dengan menggunakan program SPSS, diperoleh hasil uji t pada motivasi kerja sebagai berikut: 
Tabel 10. Hasil analisa uji $-\mathbf{t}$

\begin{tabular}{rlrrrrr}
\hline \multirow{2}{*}{ Model } & \multicolumn{2}{c}{$\begin{array}{l}\text { Unstandardized } \\
\text { Coefficients }\end{array}$} & \multicolumn{2}{c}{$\begin{array}{c}\text { Standardized } \\
\text { Coefficients }\end{array}$} & \multirow{2}{*}{ t } & Sig. \\
\cline { 3 - 5 } & & \multicolumn{1}{c}{ B } & Std. Error & Beta & & \\
\hline \multirow{2}{*}{1} & (Constant) & 2.343 & .435 & & 5.389 & .000 \\
& Motivasi & .290 & .139 & .261 & 2.096 & .040 \\
\hline
\end{tabular}

Dari tabel dapat dibaca nilai $\mathrm{t}$ atau uji $\mathrm{t}$ sebagai berikut dengan alpha a 95\% diperoleh nilai 0,05, motivasi kerja memiliki nilai signifikan 0.040 dan Koefisien 0.261 , dengan tingkat singnifikan 0.04 lebih kecil $<0.05$ berarti Ho ditolak dan Ha diterima, dari uji- $\mathrm{t}$ dapat di nyatakan bahwa motivasi memiliki hubungan yang signifikan, berarti bahwa variabel motivasi kerja berpengaruh signifikan terhadap kinerja karyawan. Dari uji secara parsial maka terpenuhi, variabel motivasi kerja, secara parsial memiliki pengaruh signifikan terhadap variabel dependen kinerja karyawan.

Tabel 11. Hasil analisa uji - F

\begin{tabular}{llrrrrr}
\hline \multicolumn{2}{l}{ Model } & $\begin{array}{c}\text { Sum of } \\
\text { Squares }\end{array}$ & df & $\begin{array}{c}\text { Mean } \\
\text { Square }\end{array}$ & F & \multicolumn{2}{c}{ Sig. } \\
\hline \multirow{3}{*}{1} & Regression & .259 & 1 & .259 & 4.395 & $.040^{\mathrm{b}}$ \\
\cline { 2 - 8 } & Residual & 3.536 & 60 & .059 & & \\
\cline { 2 - 8 } & Total & 3.795 & 61 & & & \\
\hline
\end{tabular}

Dependent Variable: Kinerja

Uji F digunakan untuk melihat, apakah variabel independen secara simultan mempengaruhi variabel kepuasan kerja. Hasil tabel, diperoleh hasil, bahwa koefiesien $\mathrm{F}$ adalah sebesar 4.395 dengan tingkat signifikansinya 0,040 Dengan alfa sebesar 0,05 diperoleh hasil bahwa Ho ditolak dan Ha diterima, dengan demikan secara simultan variabel independen: motivasi kerja, memiliki pengaruh yang signifikan terhadap variabel dependen yaitu kinerja karyawan.

Tabel 12. Hasil analisa uji $-R^{2}$

\begin{tabular}{cccrr}
\hline Model & $\mathrm{R}$ & R Square & $\begin{array}{c}\text { Adjusted R } \\
\text { Square }\end{array}$ & $\begin{array}{c}\text { Std. Error of } \\
\text { the Estimate }\end{array}$ \\
\hline 1 & $.261^{\mathrm{a}}$ & .068 & .053 & .24276 \\
\hline
\end{tabular}

Hasil nilai koefisien determinasi sebesar 0.68 seperti terlihat dalam tabel memberikan arti bahwa kinerja karyawan dijelaskan oleh variabel independen motivasi kerja sebesar 6,8 \%, sedangkan 93,2\% dijelaskan oleh variabel yang lain.

\section{Pengaruh kepuasan kerja terhadap kinerja karyawan}

Menggunakan program SPSS, diperoleh hasil uji -t pada kepuasan kerja:

Tabel 13. Hasil analisa uji - $t$

\begin{tabular}{|c|c|c|c|c|c|c|}
\hline & \multirow[t]{2}{*}{ Model } & \multicolumn{2}{|c|}{$\begin{array}{c}\text { Unstandardized } \\
\text { Coefficients }\end{array}$} & \multirow{2}{*}{$\begin{array}{c}\text { Standardized } \\
\text { Coefficients } \\
\text { Beta }\end{array}$} & \multirow[t]{2}{*}{$\mathrm{t}$} & \multirow[t]{2}{*}{ Sig. } \\
\hline & & $\mathrm{B}$ & Std. Error & & & \\
\hline \multirow{2}{*}{1} & (Constant) & 3.440 & .735 & & 4.677 & .000 \\
\hline & Kepuasan & -.061 & .239 & -.033 & -.256 & .799 \\
\hline
\end{tabular}

Andi Afrizal

JURNAL EKONOMI SYARIAH INDONESIA, Volume V, No.2 Desember 2015 
Dari tabel dapat dibaca nilai $t$ atau uji $t$ dengan alpha a $95 \%$ dengan nilai signifikan 0,05, dan kepuasan kerja memiliki nilai signifikan 0.799 dan dengan tingkat singnifikan 0.79 lebih besar $>0.05$ berarti Ho diterima dan Ha ditolak, dari uji- $\mathrm{t}$ dapat di diketahui bahwa kepuasan kerja tidak memiliki hubungan yang signifikan, berarti bahwa variabel kepuasan kerja tidak berpengaruh terhadap kinerja karyawan. Dari uji secara parsial maka tidak terpenuhi, karena dari variabel kepuasan kerja, secara parsial tidak berpengaruh terhadap variabel dependen kinerja karyawan.

Tabel 14. Hasil analisa uji - F

\begin{tabular}{rlrrrrr}
\hline Model & $\begin{array}{c}\text { Sum of } \\
\text { Squares }\end{array}$ & df & & $\begin{array}{c}\text { Mean } \\
\text { Square }\end{array}$ & \multicolumn{1}{c}{ F } & \multicolumn{1}{c}{ Sig. } \\
\hline \multirow{3}{*}{1} & Regression & .004 & 1 & .004 & .066 & $.799^{\mathrm{b}}$ \\
\cline { 2 - 7 } & Residual & 3.791 & 60 & .063 & & \\
\cline { 2 - 7 } & Total & 3.795 & 61 & & & \\
\hline
\end{tabular}

Uji F digunakan untuk melihat, apakah variabel independen secara simultan mempengaruhi variabel kepuasan kerja, hasil tabel, diperoleh nilai F adalah sebesar 0.066 dengan tingkat signifikansinya 0,799. Dengan alfa sebesar 0,05 diperoleh hasil bahwa Ho diterima dan Ha ditolak, dengan demikan secara simultan variabel independenkepuasan kerja, memiliki pengaruh yang tidak signifikan terhadap variabel dependen yaitu kinerja karyawan.

Tabel 15. Hasil analisa uji-R

\begin{tabular}{crrrr}
\hline Model & $\mathrm{R}$ & R Square & $\begin{array}{c}\text { Adjusted R } \\
\text { Square }\end{array}$ & $\begin{array}{c}\text { Std. Error of the } \\
\text { Estimate }\end{array}$ \\
\hline 1 & $.033^{\mathrm{a}}$ & .001 & -.016 & .25135 \\
\hline
\end{tabular}

Dengan menggunakan program SPSS, diperoleh hasil nilai koefisien determinasi sebesar 001 memberikan arti bahwa kinerja karyawan dijelaskan oleh variabel independen kepuasan kerja sebesar $1 \%$, sedangkan $99 \%$ dijelaskan oleh variabel yang lain.

Pengaruh gaya kepemimpinan secara simultan terhadap kinerja karyawan dimoderasi motivasi kerja

Hasil data pada tabel diperoleh hasil uji -t sebagai berikut :

Tabel 16. Hasil analisa uji-t

\begin{tabular}{|c|c|c|c|c|c|c|}
\hline & \multirow[t]{2}{*}{ Model } & \multicolumn{2}{|c|}{$\begin{array}{l}\text { Unstandardized } \\
\text { Coefficients }\end{array}$} & \multirow{2}{*}{$\begin{array}{c}\begin{array}{c}\text { Standardized } \\
\text { Coefficients }\end{array} \\
\text { Beta }\end{array}$} & \multirow[t]{2}{*}{$\mathrm{t}$} & \multirow[t]{2}{*}{ Sig. } \\
\hline & & $\mathrm{B}$ & Std. Error & & & \\
\hline \multirow{6}{*}{1} & (Constant) & .779 & 1.278 & & .609 & .545 \\
\hline & Direktif & -.378 & .335 & .134 & -1.128 & .264 \\
\hline & Suportif & .557 & .267 & .252 & 2.088 & .041 \\
\hline & Partisif & .320 & .178 & .239 & 1.794 & .078 \\
\hline & Prestasi & .253 & .162 & .213 & 1.560 & .124 \\
\hline & Motivasi & .058 & .154 & .053 & .380 & .706 \\
\hline
\end{tabular}

Dapat dilihat bahwa : variabel gaya direktif yang dimoderasi motivasi kerja tidak berpengaruh terhadap kinerja karyawan.variabel gaya suportif yang 161 dimoderasi motivasi kerja berpengaruh terhadap kinerja karyawan. bahwa 
variabel gaya partisipatif yang dimoderasi motivasi kerja tidak berpengaruh signifikan terhadap kinerja karyawan. bevariabel gaya orientasi prestasi yang dimoderasi motivasi kerja berpengaruh signifikan terhadap kinerja karyawan. Dari uji secara parsial, menggunakan t test, gaya kepemimpinan orientasi prestasi memiliki nilai signifikan 0.05 . Dari empat variabel gaya kepemimpinan yaitu gaya kepemimpinan direktif, gaya kepemimpinan suportif, gaya kepemimpinan partisipatif, dan gaya kepemimpinan orientasi prestasi, yang di moderasi oleh variabel motivasi kerja secara parsial terdapat tiga gaya kepemimpinan tidak berpengaruh signifikan, kecuali variabel gaya kepemimpinan suportif yang berpengaruh signifikan terhadap variabel dependen kinerja karyawan melalui motivasi kerja. Hasil uji F sebagai berikut:

Tabel 17. Hasil analisa uji - F

\begin{tabular}{rlrrrrr}
\hline & Model & Sum of Squares & \multicolumn{1}{c}{ df } & Mean Square & F & Sig. \\
\hline \multirow{3}{*}{1} & Regression & .993 & 5 & .199 & 3.972 & $.004^{\text {b }}$ \\
\cline { 2 - 8 } & Residual & 2.801 & 56 & .050 & & \\
\cline { 2 - 8 } & Total & 3.795 & 61 & & & \\
\hline
\end{tabular}

Dependent Variable: Kinerja

Hasil tabel diperoleh, bahwa dengan tingkat signifikansinya 0,004 dengan signifikan 0.05 hasil uji F maka Ho ditolak dan Ha diterima, dengan demikan secara simultan variabel independen :gaya kepemimpinan direktif, suportif, partisipatif, dan orientasi prestasi yang dimoderasi oleh variabel motivasi kerja memiliki pengaruh yang signifikan terhadap variabel dependen yaitu kinerja karyawan. Maka hipotesa terpenuhi.

Tabel 18. Hasil Uji - R ${ }^{2}$

\begin{tabular}{crrrr}
\hline Model & R & R Square & $\begin{array}{c}\text { Adjusted R } \\
\text { Square }\end{array}$ & $\begin{array}{c}\text { Std. Error of the } \\
\text { Estimate }\end{array}$ \\
\hline 1 & $.454^{\mathrm{a}}$ & .206 & .135 & .23191 \\
\hline
\end{tabular}

Diperoleh hasil nilai koefisien determinasi sebesar 20,6 seperti terlihat dalam tabel bahwa kinerja karyawan dijelaskan oleh variabel independen gaya kepemimpinan direktif, suportif, partisipatif, dan orientasi prestasi yang dimoderasi oleh variabel motivasi kerja sebesar 20,6\%, sedangkan 79,4\% dijelaskan oleh variabel yang lain.

\section{Pengaruh gaya kepemimpinan secara simultan terhadap kinerja dimoderasi kepuasan kerja}

Tabel 19. Hasil uji t

\begin{tabular}{|c|c|c|c|c|c|c|}
\hline & \multirow[t]{2}{*}{ Model } & \multicolumn{2}{|c|}{$\begin{array}{c}\text { Unstandardized } \\
\text { Coefficients }\end{array}$} & \multirow{2}{*}{$\begin{array}{c}\begin{array}{c}\text { Standardized } \\
\text { Coefficients }\end{array} \\
\text { Beta }\end{array}$} & \multirow[t]{2}{*}{$\mathrm{t}$} & \multirow[t]{2}{*}{ Sig. } \\
\hline & & $\mathrm{B}$ & Std. Error & & & \\
\hline \multirow{6}{*}{1} & (Constant) & .838 & 1.317 & & .636 & .527 \\
\hline & Direktif & -.404 & .353 & -.143 & -1.144 & .258 \\
\hline & Suportif & -.549 & .267 & 248 & 2.055 & .045 \\
\hline & Partisif & .342 & .167 & .255 & 2.047 & .045 \\
\hline & Prestasi & .274 & .152 & .232 & 1.805 & .076 \\
\hline & Kepuasan & 029 & .225 & -.016 & .128 & .899 \\
\hline
\end{tabular}

\section{Andi Afrizal}

JURNAL EKONOMI SYARIAH INDONESIA, Volume V, No.2 Desember 2015 
Variabel gaya kepemimpinan direktif dan orientasi prestasi yang dimoderasi kepuasan kerja berpengaruh tidak signifikan terhadap kinerja karyawan. dan variabel gaya kepemimpinan suportif dan partisipatif yang dimoderasi kepuasan kerja berpengaruh signifikan terhadap kinerja karyawan. Dari uji secara parsial, menggunakan $\mathrm{t}$ test, gaya kepemimpinan orientasi prestasi memiliki nilai 0.04 dan partisipatif 0.04 . Dari empat variabel gaya kepemimpinan yaitu gaya kepemimpinan direktif, gaya kepemimpinan suportif, gaya kepemimpinan partisipatif, dan gaya kepemimpinan orientasi prestasi, yang di moderasi oleh variabel kepuasan kerja apabila dilakukan analisa regresi secara parsial terdapat dua variabel gaya kepemimpinan secara parsial yang tidak signifikan, dan dua variabel gaya kepemimpinan yang signifikan,yaitu: gaya kepemimpinan partisipatif dan orientasi prestasi, yang berpengaruh signifikan terhadap variabel dependen kinerja karyawan melalui kepuasan kerja.

Tabel 20. Hasil uji F

\begin{tabular}{|c|c|c|c|c|c|c|}
\hline & Model & $\begin{array}{l}\text { Sum of } \\
\text { Squares }\end{array}$ & $\mathrm{df}$ & $\begin{array}{c}\text { Mean } \\
\text { Square }\end{array}$ & $\mathrm{F}$ & Sig. \\
\hline \multirow{3}{*}{1} & Regression & .987 & 5 & .197 & 3.938 & $.004^{\mathrm{b}}$ \\
\hline & Residual & 2.808 & 56 & .050 & & \\
\hline & Total & 3.795 & 61 & & & \\
\hline
\end{tabular}

Hasil pada tabel, dapat dijelaskan bahwa koefiesien $\mathrm{F}$ adalah sebesar 3.938 dengan tingkat signifikansinya 0,004 Dengan signifikan sebesar lebih kecil 0,05 maka Ho ditolak dan Ha diterima, dengan demikan secara simultan variabel independen: gaya kepemimpinan direktif, suportif, partisipatif, dan orientasi prestasi yang dimoderasi oleh variabel kepuasan kerja memiliki pengaruh yang signifikan terhadap variabel dependen yaitu kinerja karyawan maka hipotesa terima.

Tabel 21. Hasil uji $\mathbf{R}^{2}$

\begin{tabular}{|c|c|c|c|c|}
\hline Model & $\mathrm{R}$ & R Square & $\begin{array}{l}\text { Adjusted R } \\
\text { Square }\end{array}$ & $\begin{array}{l}\text { Std. Error of the } \\
\text { Estimate }\end{array}$ \\
\hline 1 & $454^{a}$ & .206 & .135 & 23192 \\
\hline
\end{tabular}

Dengan menggunakan program SPSS hasi 1 uji $R$, maka diperoleh hasil nilai koefisien determinasi sebesar 206 seperti terlihat dalam table, memberikan arti bahwa kinerja karyawan dijelaskan oleh variabel independen gaya kepemimpinan direktif, suportif, partisipatif, dan orientasi prestasi yang dimoderasi oleh variabel kepuasan kerja sebesar 20,6 \%, sedangkan 79,4 \% dijelaskan oleh variabel yang lain.

Pengaruh motivasi kerja terhadap kinerja karyawan di moderasi kepuasan kerja

Tabel 22. Hasil uji t

\begin{tabular}{llrrrrr}
\hline \multirow{2}{*}{ Model } & \multicolumn{2}{c}{$\begin{array}{c}\text { Unstandardized } \\
\text { Coefficients }\end{array}$} & \multicolumn{2}{c}{$\begin{array}{c}\text { Standardized } \\
\text { Coefficients }\end{array}$} & \multirow{2}{*}{ S } & \multirow{2}{*}{ Sig. } \\
\cline { 3 - 5 } & \multicolumn{1}{c}{ B } & Std. Error & Beta & & \\
\hline \multirow{2}{*}{1} & (Constant) & 2.480 & .853 & & 2.907 & .005 \\
& Motivasi & .289 & .140 & .260 & 2.071 & .043 \\
& Kepuasan & -.044 & .233 & -.024 & -.187 & .852 \\
\hline
\end{tabular}


Dari tabel tersebut dengan alpha a $95 \%$ diperoleh nilai signifikan 0,05, dan nilai signifikan motivasi kerja sebesar 0.04 yang dimoderasi kepuasan kerja, dengan signifikan 0.04 lebih kecil dari 0.05 maka Ho ditolak dan Ha diterima. Motivasi kerja berpengaruh signifikan terhadap kinerja karyawan melalui variabel kepuasan kerja. Dari uji secara parsial, menggunakan $t$ test, maka hipotesa terpenuhi.

Tabel 23. Hasil Uji F

\begin{tabular}{|c|c|c|c|c|c|c|}
\hline & Model & $\begin{array}{l}\text { Sum of } \\
\text { Squares }\end{array}$ & $\mathrm{df}$ & $\begin{array}{l}\text { Mean } \\
\text { Square }\end{array}$ & $\mathrm{F}$ & Sig. \\
\hline \multirow{3}{*}{1} & Regression & .261 & 2 & .131 & 2.180 & $.122^{\mathrm{b}}$ \\
\hline & Residual & 3.534 & 59 & .060 & & \\
\hline & Total & 3.795 & 61 & & & \\
\hline
\end{tabular}

Hasil tabel bahwa koefiesien $\mathrm{F}$ adalah sebesar 2.180 dengan tingkat signifikansinya 0,122 Dengan nilai signifikan sebesar 0,112 lebih bersar dari 0.05 maka Ho diterima dan Ha ditolak, dengan demikan secara simultan variabel independen : motivasi kerja yang dimoderasi oleh variabel kepuasan kerja memiliki pengaruh yang tidak signifikan terhadap variabel dependen yaitu kinerja karyawan.

Tabel 24. Hasil Uji R²

\begin{tabular}{crrrr}
\hline Model & $\mathrm{R}$ & R Square & Adjusted R Square & \multicolumn{2}{c}{$\begin{array}{c}\text { Std. Error of the } \\
\text { Estimate }\end{array}$} \\
\hline 1 & $.262^{\mathrm{a}}$ & .069 & .037 & .24473 \\
\hline
\end{tabular}

Dengan menggunakan program SPSS, hasil lihat lampiran, maka diperoleh hasil nilai koefisien determinasi sebesar 0.69 seperti terlihat dalam tabel memberikan arti bahwa kinerja karyawan dijelaskan oleh variabel independen motivasi kerja yang dimoderasi oleh variabel kepuasan kerja hanya sebesar $6.9 \%$, sedangkan 93,1 \% dijelaskan oleh variabel yang lain.

\section{Analisa Jalur}

Penelitian ini akan menggunakan analisis jalur, melihat pengaruh langsung dan tidak langsung dari analisi regresi yang sudah dilakukan, yaitu :

\section{Pengaruh Langsung}

Setelah analisa regresi, selanjutnya dilakukan analisa jalur yang merupakan pengembangan dari analisa regresi berganda, yang bertujuan untuk mengetahui efek langsung dan efek tidak langsung suatu variable. Adapun pengaruh langsung (Direct Effect), dengan menggunakan gambar di bawah ini dapat dilihat pada masing-masing nilai koefisien yaitu signifikan (S) dan tidak signifikan (TS) pada masing masing variable, adapun hasil analisa sebagai berikut pada gambar :

\section{Andi \\ Afrizal}

164

JURNAL EKONOMI SYARIAH INDONESIA, Volume V, No.2 Desember 2015 


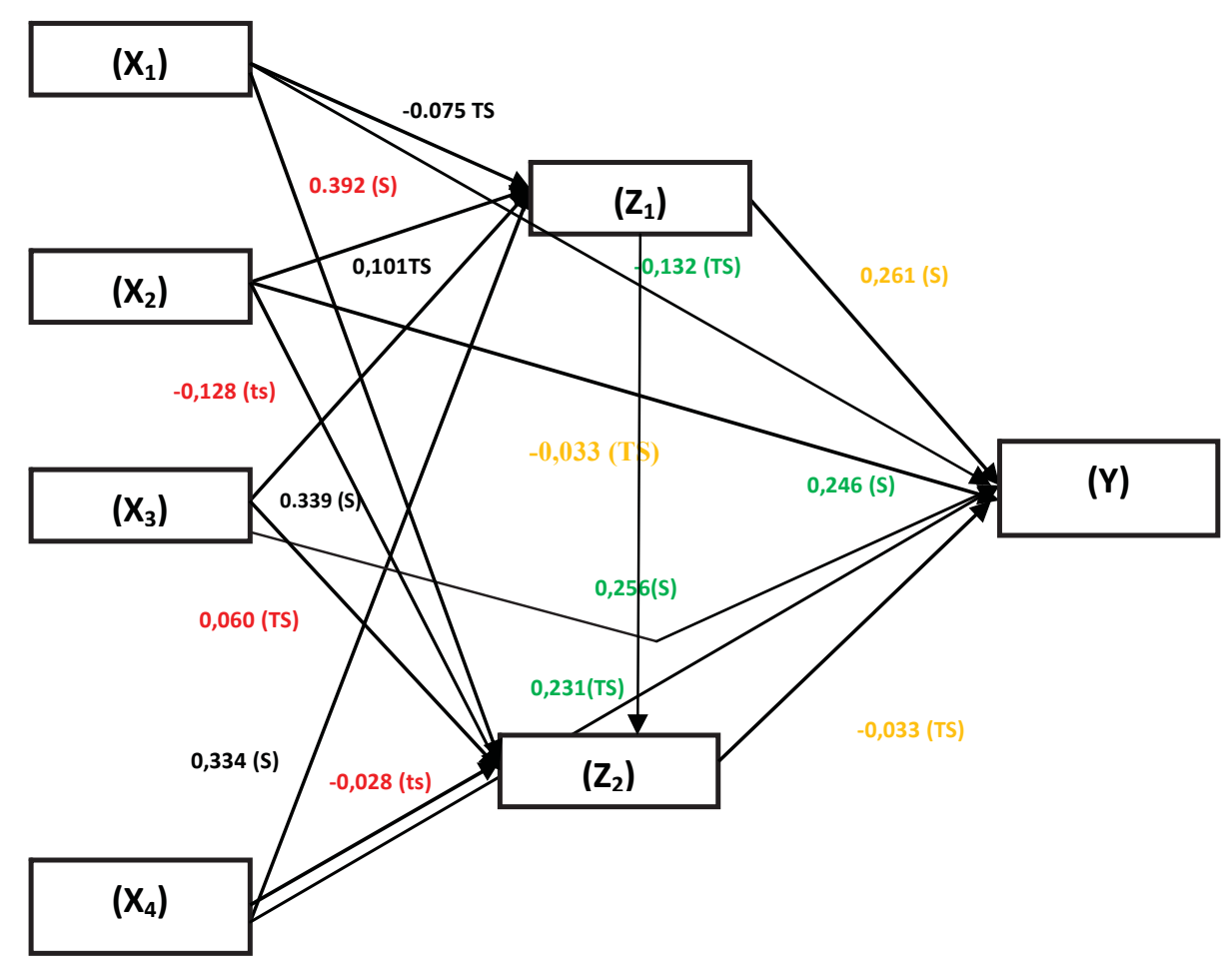

Gambar 1. Pengaruh langsung

\section{Pengaruh tidak langsung dan effect total}

Untuk melakukan penghitungan pengaruh tidak langsung (Indirect Effect), dan total effect dapat digambarkan dalam tabel sebagai berkut :

Tabel 24. Analisis Jalur

\begin{tabular}{|c|c|c|c|}
\hline & Jalur & Efek tidak langsung & Efek total \\
\hline$X_{1}$ & $Z_{1}$ & $\beta_{1.1} \beta \gamma z=-0.019$ & $\left(\beta_{1.1}, \gamma_{1.1}\right)+\beta_{y .1}=-0,151$ \\
\hline $\mathrm{X}_{2}$ & $Z_{1}$ & $\beta_{1.2} . \beta \gamma z=-0,002$ & $\left(\beta_{1.2 .} \gamma_{1.1}\right)+\beta_{y .2}=0,243$ \\
\hline$X_{3}$ & $\mathrm{Z}_{1}$ & $\beta_{1.3 .} \beta \gamma z=0,088$ & $\left(\beta_{1.3}, \gamma_{1.1}\right)+\beta_{\mathrm{y} .3}=0,344$ \\
\hline$X_{4}$ & $\mathrm{Z}_{1}$ & $\beta_{1.4 .} \beta \gamma z=0,087$ & $\left(\beta_{1.4} . \gamma_{1.1}\right)+\beta_{y .4}=0,318$ \\
\hline
\end{tabular}

Sumber : data diolah

Dari tabel tersebut terlihat bahwa variabel $X_{3}$ atau gaya kepemimpinan partisipatif memiliki efek tidak langsung tertinggi dan $X_{3}$ atau gaya kepemimpinan partipatif memiliki efek total yang terbesar, nilai $\mathrm{X}_{4}$ terbesar dalam efek tidak langsung dan efek total melalui intervening variable kepuasan kerja, variabel intervening $\mathrm{Z}_{2}$ atau Kepuasan kerja, efek tidak langsung dan efek total melalui kepuasan kerja dapat didiskripsikan sebagai berikut:

Tabel 25. Analisis Jalur

\begin{tabular}{|c|c|c|c|c|}
\hline & & & & \multirow{3}{*}{$\begin{array}{l}\text { Efek total } \\
\left(\beta_{11} \gamma_{21}\right)+\beta y_{1}=-0,148\end{array}$} \\
\hline & \multicolumn{2}{|r|}{ Jalur } & Efek tidak langsung & \\
\hline & $\overline{X_{1}}$ & $\mathrm{Z}_{2}$ & $B_{2.1} \beta \gamma z_{2}=-0,012$ & \\
\hline Pengaruh & $\mathrm{X}_{2}$ & $\mathrm{Z}_{2}$ & $B_{2.2 .} \beta \gamma z_{2}=-0,004$ & $\left(\beta_{1.2} \gamma_{2.1}\right)+\beta y_{.2}=-0,242$ \\
\hline Covoritu & $X_{3}$ & $\mathrm{Z}_{2}$ & $\mathrm{~B}_{2.3} \beta \gamma \mathrm{z}_{2}=0,0019$ & $\left(\beta_{1.3 .} Y_{2.1}\right)+\beta y_{3.3}=0,257$ \\
\hline Gaya & $\mathrm{X}_{4}$ & $\mathrm{Z}_{2}$ & $\mathrm{~B}_{24} \beta \gamma \mathrm{z}_{2}=0,0017$ & $\left(\beta_{14} \gamma_{21}\right)+\beta y_{4}=0,231$ \\
\hline
\end{tabular}

JURNAL EKONOMI SYARIAH INDONESIA, Volume V, No.2 Desember 2015 
Dari tabel tersebut terlihat bahwa variabel $X_{4}$ memiliki efek tidak langsung dan efek total yang terbesar. Dari hasil analisa jalur variable gaya kepemimpinan terhadap motivasi kerja dan kepuasan kerja terhadap kinerja karyawan $\mathrm{X}_{3}$ memiliki nilai efek tidak langsung tertinggi dan variabel $\mathrm{X}_{4}$ memiliki efek total tertinggi.

Tabel 26. Analisis Jalur

\begin{tabular}{|c|c|c|c|c|c|}
\hline \multicolumn{4}{|c|}{ Jalur } & Efek tidak langsung & Efek total \\
\hline $\mathrm{X}_{1}$ & $Z_{1}$ & & $\mathrm{Y}$ & $\beta_{11} \beta Z_{21} \beta \gamma z_{2}=-0,001$ & $\left(\beta_{11} \beta \mathrm{Z}_{21} \beta \gamma \mathrm{z}_{2}\right)+\beta \mathrm{y}_{1}=-0.101$ \\
\hline$X_{2}$ & $\mathrm{Z}_{1}$ & $\mathrm{Z}_{2}$ & Y & $\beta_{1} \quad \beta Z_{2,} \beta \gamma z_{2}=0,001$ & $\left(\beta_{1} \quad \beta Z_{2} \beta \gamma_{2}\right)+\beta y_{2}=-0.043$ \\
\hline 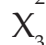 & $\mathrm{Z}_{1}$ & $\mathrm{Z}_{2}$ & $\mathrm{Y}$ & $\beta_{13} \beta Z_{21} \beta \gamma z_{2}=0,003$ & $\left(\beta_{13} \beta z_{21} \beta z_{2}\right)+\beta y_{3}=0.339$ \\
\hline $\mathrm{X}_{4}$ & $\mathrm{Z}_{1}$ & $Z_{2}$ & Y & $\beta Z_{21} \beta \gamma z_{2}=0,003$ & $\left(\beta_{14} \quad \beta Z_{2} \beta \gamma z_{2}\right)+\beta y_{4}=0.280$ \\
\hline
\end{tabular}

Sumber : data diolah

Dari analisa jalur ini dapat di jelaskan bahwa gaya kepemimpinan partisipatif dan orientasi prestasi merupakan gaya kepemimpinan yang memiliki pengaruh atau jalur yang dapat dipakai dalam meningkatkan kinerja melalui motivasi kerja dan kepuasan kerja karyawan pada BMT BIF.

\section{Determinasi total}

Nilai ini diperoleh dengan menggunakan formula sebagai berikut :

$$
\begin{aligned}
& R^{2} \text { total }=1-\left(1-\mathrm{R}_{1}^{2}\right) \cdot\left(1-\mathrm{R}_{2}{ }_{2}\right) \\
& \mathrm{R}^{2} \text { total }=1-(1-0,312) \cdot(1-0,109) \\
& \quad=1-(0,688) \cdot(0,891) \\
& \mathrm{R}^{2} \text { total }=1-0.613=0.386
\end{aligned}
$$

Nilai determinasi dalam analisa determinasi total diperoleh hasil nilai determinasi sebesar $38.6 \%$ hal ini menunjukan bahwa kinerja karyawan di BMT BIF dapat dijelaskan oleh variabel gaya kepemimpinan direktif, gaya kepemimpinan partisipatif, gaya kepemimpinan suportif, dan gaya kepemimpinan orientasi prestasi dengan variabel perantara motivasi kerja dan kepuasan kerja.

\section{KESIMPULAN}

Hasil analisa dan uji data dilakukan melalui Program SPSS 16 yang telah dikemukakan berkaitan pengaruh antara variable independent , variable intervening dan dependent yaitu Pengaruh gaya kepemimpinan kepemimpinan directif, suportif, partisipatif dan orientasi prestasi, motivasi kerja dan kepuasan kerja terhadap kinerja karyawan dapat disimpulkan beberapa hal dalam penelitian ini sebagai hasil pengujian hipotesis, sebagai berikut:

Gaya kepemimpinan direktif secara parsial tidak berpengaruh secara signifikan terhadap motivasi kerja.

Gaya kepemimpinan suportif secara parsial tidak berpengaruh terhadap motivasi kerja

Gaya kepemimpinan partisipatif secara parsial memiliki pengaruh positif terhadap motivasi kerja

Gaya kepemimpinan orientasi prestasi, secara parsial memiliki pengaruh positif terhadap motivasi kerja.

Andi

Afrizal

166

JURNAL EKONOMI SYARIAH INDONESIA, Volume V, No.2 Desember 2015 
Gaya kepemimpinan secara simultan memiliki pengaruh positif terhadap motivasi kerja.

Gaya kepemimpinan direktif, secara parsial memiliki pengaruh positif terhadap kepuasan kerja.

Gaya kepemimpinan suportif secara parsial tidak memiliki pengaruh positif terhadap kepuasan kerja.

Gaya kepemimpinan partisipatif secara parsial tidak memiliki pengaruh positif terhadap kepuasan kerja.

Gaya kepemimpinan orientasi prestasi secara parsial tidak memiliki pengaruh positif terhadap kepuasan kerja.

Gaya kepemimpinan secara simultan tidak berpengaruh positif terhadap kepuasan Kerja.

Gaya kepemimpinan direktif secara parsial tidak berpengaruh positif terhadap kinerja karyawan.

Gaya kepemimpinan suportif secara parsial berpengaruh positif kinerja karyawan.

Gaya kepemimpinan partisipatif secara parsial memiliki pengaruh positif terhadap kinerja karyawan.

Gaya kepemimpinan orientasi profesi secara parsial memiliki pengaruh positif terhadap kinerja karyawan.

Gaya kepemimpinan secara simultan memiliki pengaruh positif terhadap kinerja karyawan.

Motivasi kerja, secara parsial memiliki pengaruh positif terhadap kinerja karyawan.

Kepuasan kerja secara parsial tidak berpengaruh positif terhadap kinerja karyawan.

Gaya Kepemimpinan secara simultan yang di moderasi oleh variabel motivasi kerja memiliki pengaruh positif terhadap kinerja karyawan.

Gaya Kepemimpinan secara simultan yang dimoderasi oleh variabel kepuasan kerja memiliki pengaruh positif terhadap dependen kinerja karyawan.

Motivasi kerja yang dimoderasi kepuasan kerja berpengaruh positif terhadap kinerja karyawan

Setelah melakukan analisa regresi dilanjutkan dengan analisis jalur,hasil dari analisi jalur pengaruh tidak langsung melalui intervening variable motivasi kerja, gaya kepemimpinan partisifatif dan yang tertinggi dengan efek total memiliki nilai yang tertinggi, pengaruh tidak langsung melalui intervening variable kepuasan kerja gaya kepemimpinan partisipatif, memiliki nilai yang tertinggi dan efek total memiliki nilai yang tertinggi,dan pengaruh tidak langsung melalui intervening variable motivasi kerja bersamaan dengan kepuasan kerja gaya kepemimpinan partisipatif, memiliki nilai yang tertinggi dan efek total memiliki nilai yang tertinggi, Dari hasil penelitian ini gaya kepemimpinan partisipatif memiliki pengaruh positif terhadap peningkatan motivasi kerja dan kepuasan kerja karyawan dan pada akhirnya akan meningkatkan kinerja karyawan pada BMT BIF.

\section{Pengaruh}

Gaya 


\section{DAFTAR PUSTAKA}

Awan U.N, Riffat, Zaidi,N.Nayyar,dkk, 2011, " Task Stucture as Moderator of College Principals' Leadership Behavior and Their Subordinates' Outcomes Journal Internatinal Education Studies Vo1.4,No 1, EBSCO

Aziz ,Amin, (2005). Pedoman Penilaian kesehatan BMT Pinbuk Press. Jakarta.

Beckly, Susan Elanour, 1977, The Path Goal Theory Of Leadership: A Test in The Commercial Television Station Situation, Dessertation, Ohio University, USA.

B1ank, Warren, Waitzel, R John, G green, Stephen, 1990, “A Test of The Situational Leadership Theory", The leadership Group Maharishi Internasinal, syracuse University, Purdue University, Personnel Psychology Int Journal. EBSCO

Brahmasari, Ida Ayu, 2004, Pengaruh Variabel Budaya Perusahaan terhadap Komitmen Karyawan dan Kinerja Perusahaan ", Kelompok Penerbitan Pers Jawa Pos, Disertai Universitas Airlangga, Surabaya

Brahmasari Ida Ayu, Agus Suprayetno, 2008, "Pengaruh motivasi kerja, kepemimpinan, budaya organisasi, terhadap kepuasan kerja karyawan serta dampak pada kinerja perusahaan studi kasus pada P.T. Pei Hai Internasional Wiratama Indonesia", jurnal manajemen dan kewirausahaan.vol 10 No.2 124-135

Coffey, E Robert, Curttis Cook, Hunsaker Phillip, 1994, Management and Organizational Behaviour, Austern Press,USA

Curtis, Maning, 2007, The art of Leadership, Second Edition Mc Graw Hill USA

Dixon Marva, Laura Kozkosky Hart, 2011, “The Impact of the goal leadership styles on Group Effectiveness and Turnover Intention", Journal of Managerial Issues, vol XXII, No. 1 Proquest. 52-69

Dubrin Andrew J., 2005, Leadership (Terjemahan), Edisi Kedua, Prenada Media, Jakarta.

Ermayanti Dwi, Thoyib Armanu, 2001, "Pengaruh Factor Motivasi Terhadap Prestasi Kerja Karyawan Pada Kantor Perum Perhutani Unit II Surabaya", Jurnal Fakultas Ekonomi Universitas Brawijaya.

Faustino Cardoso Gomes, 2000, Manajemen sumberdaya Manusia, Andi Offset, Yogyakarta

Fukushige, Aya, Spincer P, David, 2011, "Leadership and Follows' Work goals:Comparison between Japan and UK," The Internasinal Journal Resource Management,vo1.22,No.10 June. Ebsco.2110-2134

House,Robert and Terence R. Mitchell (1974) "path-goal Theory of leadership" Journal of contemporary business 81-97 journal Proquest No 2 Hal 124-135

Hatmaninggita, Ratih, 2008, Analisis Kepemimpinan Suvior distribusi dan penjualan terhadap steres kerja kayawan pada PT Heinz ABC Indonesia cabang Bogor.

Hersey,Paul, Blanchard,H.Kenneth, 1992, Manajemen Prilaku Organisasi, edisi empat,Erlangga, Jakarta

Handoko Hani, 1998, Manajemen Personalia Dan Sumber Daya Manusia, Edisi 2, BPFE, Yogyakarta

Andi

Afrizal

168

JURNAL EKONOMI SYARIAH INDONESIA, Volume V, No.2 Desember 2015 
Hadi,Sjamsoel, 2006, Pengaruh Gaya Kepemimpian Terhadap Motivasi dan Kepuasan Kerja serta Kinerja Karyawan pada PT.Bank Sentral Asia Tbk. Wilayah Jawa Timur, Disertasi Program Pasca Sarjana Universitas Airlangga Surabaya.

Jerald Greenberg and Robert A. Baron, 2003, Behavior in Organizations, Eight Edition, prentice hall Pearson Education International. New Jersey,US

Gibson, Ivancevich, Donnely, 1997, Organizations Behavior (Terjemahan), Cetakan Keempat, PT. Gelora Aksara Pratama, Jakarta

Kartono Kartini, 1998, Pemimpin Dan Kepemimpinan, Raja Garindo, Perasadam Jakarta.

Kreifier Robert, Kinicki Angelo, 2005, Organizational Behavior (Terjemahan) Buku 1, Edisi Kelima, Salemba Empat, Jakarta

Koesmono. H., 2005, "Pengaruh Budaya Organisasi Terhadap Motivasi dan Kepusaan Kerja Serta Kinerja karyawan Pada Pada sud Sektor Industri Pengelolaan Kayu Ekspor Di jawa timur" , Disertasi Universitas Airlangga, Jurnal Majemen kewirausahaan vol 7 No. 2. Surabaya

Meija,L.R. Gomes, Balkin, B. David, Cardy,L.Robert, 2001, Managing Human Resources, Third Edition,(New Jersey, Prentice Hall,USA

Mangkunegara Anwar Prabu, 2005, Manajemen Sumber Daya Organisasi, Cetakan Keenam, PT. Remaja Rodakarya, Bandung

Mangkunegara Anwar Prabu, 2005, Perilaku dan Budaya Organisasi, Cetakan Pertama, PT. Refika Aditama, Bandung

Nazir Moh, 1998, Metode Penelitian, Ghalia Indonesia. Jakarta

Nimran, Umar, 2004, Perilaku Organisasi. Cetakan Ketiga, CV. Citra Media, Surabaya

Nawawi, Hadari, Kepemimpinan yang Ejektif, Gajah Mada University Press, Yogyakarta

Nisa, Awan Riffat, Raza Zaidi Nayyar, Naz Anjum, Noureen, Ghazala, 2011, "Task Structure as Moderator of College Principals' Leadership Behavior and Their Subordinates", Outcomes,International Education Studies Journal,Vol.4 No I EBSC0.134-143

Oshborn,Daniel, Rothenberg, 2008, Leverage Points 11 Tip Membangkitkan motivasi Karyawan,Prestasi Pusaka ,Jakarta

Robbins, Stephen P, 2001, Organizational Behaviro (terjemahan) Iilid 1, Edisi Kedelapan, PT. Bhuana Ilmu Populer, Jakarta.

Ropke, Jochen, 2002, Ekonomi Koperasi Teori dan Manajemen, Salemba Empat, Jakarta

Rivai,Veithzal, 2004, Manajemen Sumher Daya Manusia untuk Perusahaan,Raja garindo,Jakarta

Rival, Veithzal, 2005, Performance Appraisal, Raja garindo, Jakarta

Siagian,Sondang P, 2002, Kiat Meningkatkan Produktivitas Kerja, Cetakan Pertama, PT. Rineka Cipta, Jakarta

Santoso, Singgih, 2002, SPSS vesi 1O,Mengolah Data Statistik Secara Proporsioanl, Elex Media Koputido,Jakarta

Sumodiningrat, Gunawan, 1995, Ekonomimetrika, BPFE, Yogyakarta.

JURNAL EKONOMI SYARIAH INDONESIA, Volume V, No.2 Desember 2015 
Suharsimi, Arikunto, 2002, Prosedur Penelitian suatu Pendekatan Praktek, cetakan dua belas, Rineka Cipta, Jakarta

Silverthorne, Colin, 2001, A test of the path goal Leadership theory in Taiwan. Leadership and organization Development journal. EBSCO. I51-158

Susilo, Martoyo, 1996, Manajemen Sumber Daya Manusia, BPFE, Yogyakarta

Syaflan, Meidi, 2013, "Tipologi Governance Baitul Maal Wat Tamwil (BMT) di daerah Istimewa Yogyakarta," Disertasi program Pasca Sarjana Fakultas Ekonomi Universitas Islam Indonesia.

Tika H. Moh. Pabundu, 2006, Budaya Organisasi dan Peningkatan Kinerja Perusahaan, cetakan Pertama, PT. Bhumi Aksara, Jakarta

Prasetyawati, Eka, 2009, "presepsi karyawan atas Hubungan gaya Kepemimpinan situasional Suvervisor Terhadap Kinerja Bagian Perawatan Bangunan dan Pasilitas Pada PT. Pajar Mekar Indah Jakarta", Tesis S2 Universitas Indonesia, Jakarta.

Widarjono, Agus, 2001, Analisa Statistika Multivariat Terapan, UPP STIM YKPN, Yogyakarta

Wahjosumijo, 1985, Kepemimpinan dan Motivasi,Ghalia Indonesia,Jakarta

Wibowo, 2006, Manajemen Kinerja, Grafindo Persada,Jakarta.

Widodo, 2011, Pengaruh Gaya Kepemimpinan, Budaya organisasi, dan motivasi kerja terhadap kinerja guru, Jurnal Pendidikan Penabur No.17/Tahun ke-12

Wuryaningrum, Febriana dan Prasetyo, Ari, 2011, Pengaruh gaya Kepemimpinan dengan Path Goal Teory Terhadap Prestasi Kerja Dosen dengan Kharakteristik lingkungan dan Kharakteristik bawahan sebagai variable Moderator alamat: http://www.lppm.unair.ac.id/

Wibisisono,darmawan, 2006, Manajemen Kinerja, Konsep, Desain, dan Tehnik Meningkatkan Daya Saing Perusahaan, Erlangga, Jakarta.

Yulk, Gary, 2005, Kepemimpinan dalam Organisasi, PT Indeks, Jakarta.

Yasin, Azis, 2001, Pepemimpinan dalam pengembangan organisasi, Jurnal Lintas Ekonomi Fakultas Ekonomi Universitas Brawijaya Malang,Volume 18 No I ,Malang.

Resmiati, Antin, 2011, Pengaruh, gaya kepemimpinan terhadap motivasi kerja anggota pada kelompok usaha bersama di Surakarta. Skripsi $\mathrm{Ma}$ 